\title{
STATUS KARIES DAN KADAR FLUOR YANG DIKONSUMSI PENDUDUK USIA 12 - 14 TAHUN DI DESA WIAU LAPI BARAT
}

\author{
${ }^{1}$ Agie Leondra \\ ${ }^{2}$ Paulina Gunawan \\ ${ }^{2}$ Dinar Wicaksono
}
${ }^{1}$ Mahasiswa Program Studi Kedokteran Gigi Fakultas Kedokteran Universitas Sam Ratulangi
${ }^{2}$ Program Studi Kedokteran Gigi Fakultas Kedokteran Universitas Sam Ratulangi
Email:dn2112av@gmail.com

\begin{abstract}
Dental caries is microbiological disease on dental hard tissue which caused localized demineralization from inorganic structure and destruction of organic substantive part of dental. Fluor protects teeth from caries, by deliberating metabolism of plaque bacteria which could make carbohydrate fermentation through hydroxide-apatite transform into fluor-apatite which more stabilize and acid resistant. The aim of this research is to identify the rate of caries grade among adolescent aged $12-14$ years and the amount of fluor proportion by consumed in the daily consumed West Wiau Lapi village. This research is descriptive cross-sectional research. Respondent amount is 59 and this research using total sampling method. The result of caries degree is calculated by DMF-T index and fluor analyzing using Spectrofotometer and the length of wave is $525 \mathrm{~nm}$. This research concluded that the caries grade arrange in intermediate degree, and the fluor amount posture is very low.
\end{abstract}

Keyword: caries grade, fluor amount

\begin{abstract}
Abstrak: Karies gigi adalah penyakit mikrobiologis struktur keras gigi yang menyebabkan demineralisasi terlokalisasi dari bagian inorganik dan kerusakan dari substansi organik yang berawal dari permukaan eksternal dari gigi. Fluor berfungsi melindungi gigi dari karies, dengan cara menghambat metabolisme bakteri plak yang dapat memfermentasi karbohidrat melalui perubahan hidroksi-apatit pada enamel menjadi flour-apatit yang lebih stabil dan lebih tahan terhadap pelarutan asam. Tujuan penelitian ini untuk mengetahui gambaran derajat karies anak-anak usia 12-14 tahun dan kadar fluor dalam air minum yang dikonsumsi di desa Wiau Lapi Barat. Penelitian ini merupakan penelitian deskriptif potong lintang. Penelitian ini menggunakan metode total sampling dan mempunyai responden penelitian berjumlah 59 orang. Hasil perhitungan derajat karies dihitung dengan indeks DMF-T dan uji fluor digunakan alat spektrofotometer dengan panjang gelombang 525 nm, dari hasil penelitian disimpulkan bahwa derajat karies di desa Wiau Lapi Barat dalam status menengah dan kandungan fluor sangat rendah.
\end{abstract}

Kata kunci: status karies, kadar fluor

Karies adalah proses demineralisasi yang disebabkan oleh suatu interaksi antara mikroorganisme, karbohidrat dalam makanan dan email. Karies yang tidak ditangani dengan baik akan berpengaruh pada derajat kesehatan dan asupan gizi. Karies menyebabkan remineralisasi dari lapisan enamel dan menurunkan kepadatan substansi organik dari gigi. ${ }^{1}$
Berdasarkan laporan Riset Kesehatan Dasar (RISKESDAS) tahun 2007 di Indonesia, prevalensi nasional karies aktif ialah 43,4 \% dan indeks DMF-T nasional ialah 4.85. Wilayah Sulawesi Utara mempunyai prevalensi karies aktif sebesar 47,4\% dan nilai indeks DMF-T provinsi Sulawesi Utara 5,01. Data ini menunjukkan bahwa prevalensi karies aktif dan nilai 
indeks DMF-T di Sulut lebih tinggi dari rata-rata nasional. ${ }^{2}$

Prevalensi karies yang tinggi ini erat hubungannya dengan kondisi email gigi. Email gigi yang mengandung fluor yang cukup akan menyebabkan gigi lebih tahan terhadap karies, karena tidak mudah larut oleh asam. Fluor termasuk golongan mikromineral yang berperan dalam proses mineralisasi dan pengerasan email gigi. Fluor ini berperan dalam pembentukan email gigi dan membuat struktur gigi lebih kuat. $^{3}$

Setiap daerah mempunyai kadar fluor yang relatif berbeda-beda, dipengaruhi oleh musim, karakeristik geologi, kimia dan fisik akuifer, porositas tanah dan kegiatan unsur kimia lain. Pada umumnya daerah pegunungan mempunyai kadar lebih rendah dibandingkan daerah pesisir pantai karena di daerah pesisir, kandungan mineral dari laut akan meresap ke sumber air tanah di daerah pesisir pantai. Tinggi rendahnya kadar fluor suatu daerah dapat dilihat dari kandungan fluor dalam air tanahnya. ${ }^{4}$

Desa Wiau Lapi Barat merupakan salah satu desa yang berada di pegunungan dan sumber air minum berasal dari sumber air lingkungan. Kadar fluor yang terkandung dalam air dapat memengaruhi tinggi rendahnya status karies di daerah tersebut.Tahun 2012 penulis pernah menjalani Kuliah Kerja Nyata di lokasi ini.Berdasarkan pengamatan penulis banyak anak di desa ini menderita karies. Alasan inilah yang mendasari penulis untuk melakukan penelitian tentang status karies dan kadar fluor di desa Wiau Lapi Barat kecamatan Tareran kabupaten Minahasa Selatan.

\section{Metode Penelitian}

Penelitian ini ialah suatu penelitian deskriptif dengan metode potong lintang.Lokasi penelitian di desa Wiau Lapi Barat kecamatan Tareran, kabupaten Minahasa Selatan dan berlangsung dari bulan Oktober 2013. Populasi pada penelitian ini ialah anak - anak berusia 12 14 tahun di desa Wiau Lapi Barat, kecamatan Tareran, kabupaten Minahasa Selatan dan Berdasarkan survei awal berjumlah 59 orang. Kriteria inklusi dalam penelitian ini ialah izin orang tua untuk dijadikan subjek penelitian. Mengonsumsi air minum sumur dan bukan air minum dalam kemasan, berada dalam periode gigi permanen dan bersifat kooperatif selama pengambilan data. Kriteria eksklusi di penelitian ini ialah tidak hadir sewaktu proses pengambilan sampel. Teknik pengambilan sampel yang digunakan pada penelitian ini yaitu total sampling, dimana seluruh anggota populasi dijadikan sebagai sampel.Variabel yang diteliti pada penelitian ini yaitu status karies dan kadar fluor air yang dikonsumsi.

Status karies adalah kondisi yang menggambarkan pengalaman karies di kurun waktu tertentu anak - anak usia 12 14 tahun di desa Wiau Lapi Barat, kecamatan Tareran, kabupaten Minahasa Selatanyang dihitung dengan indeks DMF-T (Deceyed missing filling teeth). Indeks DMF-T ialah indeks yang digunakan pada gigi permanen untuk menunjukkan banyaknya gigi yang terkena karies. D (Decayed): Lubang pada gigi akibat dekalsifikasi jaringan email gigi yang terlihat keputih-putihan atau kecoklatan dengan ujung sonde terasa menyangkut pada kavitas. M (Missing) : Hilangnya gigi permanen karena telah tanggal atau dicabut, maupun karies gigi permanen yang diindikasikan untuk pencabutan, seperti jika mahkota gigi tidak ada atau hanya tinggal akar. F (Filling): Tambalan atau tumpatan pada gigi permanen baik secara tetap maupun berupa tambalan sementara.Kategori DMF-T menurut WHO antara lain; sangat rendah $(0,8-1,1)$, rendah $(1,2-2,6)$, sedang $(2,7-4,4)$, tinggi $(4,5-6,5)$, sangat tinggi $(>6,6)$.

Kadar fluor air yang dikonsumsi adalah jumlah kandungan fluor dalam sumber air yang berasal dari sumber air jaga dan ditampung dalam 4 bak penampungan air di 4 jaga desa yang pengukurannya menggunakan analisis spektrofotometer dengan panjang gelombang $525 \mathrm{~nm}$ dan 
hasil pengukurannya dinyatakan dalam satuan part per million (ppm).

Kadar fluor air yang dikonsumsi berdasarkan kebutuhan asupan fluor tambahan dikategorikan menjadi empat, yaitu ppm sangat rendah $(0,0-0,3 \mathrm{ppm})$, rendah $(0,3-0,7 \mathrm{ppm})$, sedang $(0,7-1,5$ ppm), tinggi (lebih dari 1,5 ppm). Instrumen Penelitian yang digunakan ialah Formulir pemeriksaan indeks DMF-T dan Alat Spektrofotometer $525 \mathrm{~nm}$ untuk memeriksa kadar fluor dalam air minum. Materi penelitian yang digunakan ialah satu set alat diagnostik set yaitu kaca mulut, sonde, alat bantu penerangan, nierbeken untuk tempat alat, pinset, cotton roll, wadah untuk sterilisasi, kapas untuk mengisolasi bagian gigi yang akan diperiksa, masker, sarung tangan, alat tulis menulis., Alumunium foil, selotip, dan cool box dan 4 botol bening dan tutup sumbat untuk menampung sampel air minum. Bahan penelitian berupa gigi geligi yang akan diteliti status kariesnya dan sampel air untuk diuji kadar fluornya.

Penelitian dilaksanakan setelah memperoleh pertimbangan etik yaitu izin melaksanakan penelitian dari kepala desa Wiau Lapi Barat kecamatan Tareran kabupaten Minahasa Selatan, serta surat persetujuan orang tua responden. Data primer diambil dari indeks DMF-T yang diambil dari hasil perhitungan indeks DMF$\mathrm{T}$ rata-rata responden yang dihitung berdasarkan hasil pemeriksaan intra oral decay, missing, filling responden dan kadar flour dalam air yang diambil dari hasil analisis spektrofotometer dengan panjang gelombang $525 \mathrm{~nm}$. Data sekunder gambaran umum desa Wiau Lapi Barat meliputi data jumlah penduduk, geografis desa, mata pencaharian diambil dari profil desa Wiau Lapi Barat.

\section{Hasil Penelitian}

Desa Wiau Lapi Barat terletak di kecamatan Tareran kabupaten Minahasa Selatanprovinsi Sulawesi Utara. Sebelah Utara daerah ini berbatasan dengan desa Talaitad kecamatan Suluun-Tareran,sebelah Selatan berbatasan dengan desa Rumoong
Atas, di sebelah Timur berbatasan dengan desa Wiau Lapi dan sebelah Barat berbatasan dengan desa Pinapalangkow, kecamatan Suluun-Tareran.

Luas wilayah desa Wiau Lapi Barat sebesar $345 \mathrm{Ha}$,dengan tinggi wilayah 580 mdpl dan bersuhu sekitar $22-29^{\circ} \mathrm{C}$. Berdasarkan sensus tahun 2012 desa ini dihuni oleh 273 kepala keluarga. Jumlah penduduk laki-laki berjumlah 443 orang dan jumlah penduduk perempuan berjumlah 420 orang.

Penduduk di desa ini pada umumnya berprofesi sebagai petani enau, padi, maupun cengkeh. Mayoritas penduduk di desa Wiau Lapi Barat berpendidikan sampai SMA dan sederajat, hanya sedikit yang berlanjut sampai pendidikan `Strata 1.

Sumber air di desa ini belum di aliri oleh perusahaan daerah air minum sehingga penduduk di desa ini mengupayakan sendiri pengelolaan sumber daya air.Sumber air di desa ini diambil dari 4 sumur galian, lalu kemudian ditampung dalam 4 bak air jaga desa.Air yang di tamping dalam 4 bak air jaga desa itu kemudian disalurkan menurut jadwal penyaluran air warga.

Penulis melihat rata-rata rumah warga disini mempunyai tempat penampungan sendiri untuk menampung air sewaktu penyaluran dari bak air desa. Penampungan ini dilakukan karena rata-rata air mengalir hanya 2 hari sekali. Air inilah yang menjadi air konsumsi warga di desa Wiau Lapi Barat.

Karakteritik subjek penelitian dikategorikan berdasarkan jenis kelamin dan usia. Data dibawah ini menunjukkan distribusi sampel berdasarkan usia dan jenis kelamin.

Tabel 1. Distribusi responden berdasarkan usia dan jenis kelamin

\begin{tabular}{lcccccc}
\hline Usia & \multicolumn{2}{l}{ Perempuan } & \multicolumn{2}{l}{ Laki - Laki } & \multicolumn{2}{l}{ Total } \\
\cline { 2 - 7 } & n & $\%$ & n & $\%$ & N & $\%$ \\
\hline 12 tahun & 13 & $22.03 \%$ & 11 & $18,68 \%$ & 24 & $40,67 \%$ \\
13 tahun & 11 & $18,68 \%$ & 8 & $13,55 \%$ & 19 & $32,20 \%$ \\
14 tahun & 9 & $15,25 \%$ & 7 & $11,86 \%$ & 16 & $27,11 \%$ \\
\hline Total & 33 & $55,93 \%$ & 26 & $44,07 \%$ & 59 & $100 \%$ \\
\hline
\end{tabular}


Sampel yang diteliti berdasarkan usia dan jenis kelamin terbagi berjenis kelamin perempuan berusia 12 tahun sebanyak 13 orang (22,03\%), berjenis kelamin laki-laki berusia12 tahun sebanyak 11 orang (18,68\%), berjenis kelamin perempuan berusia 13 tahun sebanyak 11 orang (18,6\%), berjenis kelamin laki-laki berusia 13 tahun sebanyak 8 orang (13,55\%), berjenis kelamin perempuan berusia 14 tahun sebanyak 9 orang ( $15,25 \%)$, dan berjenis kelamin laki-laki berusia 14 tahun sebanyak 7 orang $(11,86 \%)$

Tabel 2. Distribusi frekuensi indeks DMF-T rata-rata responden berjenis kelamin laki - laki berdasarkan usia.

\begin{tabular}{lccc}
\hline Usia & $\mathrm{N}$ & $\%$ & Indeks DMF-T Rata - Rata \\
\hline 12 & 11 & 42,30 & 3,36 \\
13 & 8 & 30,76 & 2,5 \\
14 & 7 & 26,92 & 2,85 \\
\hline Total & 26 & 100 & 2,90 \\
\hline
\end{tabular}

Data diatas menunjukkan bahwa pada penduduk berjenis kelamin laki-laki yang berusia 12 tahun indeks DMF-T sebesar 3,36 dan berusia 13 tahun sebesar 2,5 dan usia 14 tahun sebesar 2,85.

Tabel 3. Distribusi frekuensi indeks DMF-T rata-rata responden berjenis kelamin perempuan berdasarkan usia.

\begin{tabular}{lllc}
\hline Usia & $\mathrm{N}$ & $\%$ & Indeks DMF-I Rata - Rata \\
\hline 12 & 13 & 39,39 & 3,06 \\
13 & 11 & 33,33 & 2,7 \\
14 & 9 & 27,27 & 2,59 \\
\hline Total & 33 & 100 & 2,81 \\
\hline
\end{tabular}

Data di atas menunjukkan bahwa pada penduduk berjenis kelamin perempuan usia 12 tahun mempunyai indeks DMF-T sebesar 3,36 , usia 13 tahun sebesar 2,5, dan berusia 14 tahun sebesar 2,33.
Tabel 4. Distribusi frekuensi status karies berdasarkan kategori WHO.

\begin{tabular}{lccc}
\hline Status karies & Standar WHO & Frekuensi (n) & Persentase (\%) \\
\hline Sangat rendah & $0-1,1$ & 7 & $11,86 \%$ \\
Rendah & $1,2-2,6$ & 19 & $32,20 \%$ \\
Sedang & $27,-4,4$ & 28 & $47,45 \%$ \\
Tinggi & $4,4-6,5$ & 5 & $8,47 \%$ \\
Sangat Tinggi & $>6,6$ & 0 & $0 \%$ \\
\hline Total & & 59 & $100 \%$ \\
\hline
\end{tabular}

Hasil pemeriksaan karies gigi berdasarkan DMF-T pada sampel di desa Wiau Lapi Barat menunjukkan 7 orang $(11,86 \%)$ mempunyai status karies sangat rendah, 19 orang dengan status karies rendah (32,2\%), 28 orang dengan status karies sedang $(47,45 \%)$, dan 5 orang dengan status karies tinggi $(8,47 \%)$, dan tidak ada yang masuk dalam status karies sangat tinggi.Data diatas menunjukkan sampel penelitian dengan persentase terbesar yaitu status karies sedang berjumlah 28 orang (47,45\%), dan persentase terkecil yaitu status karies sangat tinggi yaitu 0 orang.

Pemeriksaan sampel air yang diambil di 4 sumber air yang berada di desa Wiau Lapi Barat pada bulan Oktober 2013 dilakukan di Balai Riset dan Standarisasi Nasional Sulawesi Utara. Sampel yang diteliti sebanyak 4 sampel. Analisa 4 sampel air yang diambil di 4 sumber desa Wiau Lapi Barat menggunakan alat spektrofotometer dengan panjang gelombang $525 \mathrm{~nm}$.

Tabel 5. Distribusi Kadar fluor dalam sampel air

\begin{tabular}{lc}
\hline Lokasi. Pengambilan & Sampel Ka dar Fluor $(\mathrm{ppm})$ \\
\hline Sumber air Jaga I & $0,00 \mathrm{l}$ \\
Sumber air Jaga II & 0,00 \\
Sumber air Jaga III & 0,00 \\
Sumber air Jaga IV & 0,00 \\
\hline
\end{tabular}

Berdasarkan analisa didapati bahwa empat sampel yang diambil dengan alat spektrofotometer menunjukkan hasil yang sama yaitu $0,00 \mathrm{ppm}$. Alat yang digunakan 
oleh penulis memiliki keterbatasan sehingga hanya bisa mendeteksi kandungan fluor sampai dua digit di belakang koma.Kandungan fluor di sumber air di desa Wiau Lapi Barat ada, tetapi konsentrasinya kecil. Jika mendeteksi dengan alat yang tingkat pengukuran lebih detail maka hasil fluor yang didapat akan lebih teliti lagi.

\section{BAHASAN}

Hasil penelitian indeks DMF-T rata-rata penduduk desa Wiau Lapi Barat yang berusia $12-14$ tahun sebesar 2,81. Hasil ini didapat dari nilai total perhitungan indeks DMF-T sebesar 161 dibagi dengan jumlah sampel yang diteliti yaitu 59 sampel. Angka ini menunjukkan bahwa rata-rata penduduk desa Wiau Lapi Barat memiliki 3 gigi yang mengalami karies.Status karies ini menggambarkan status karies penduduk desa masuk kategori sedang.

Penulis juga melihat bahwa sebesar 28 orang $(47,45 \%)$ atau mayoritas status karies penduduk berada dalam status sedang. Hasil penelitian ini juga didukung oleh penelitian Noerwida di kabupaten Kendal yang menunjukkan angka prevalensi karies paling banyak terjadi pada anak-anak dengan kategori sedang sejumlah 70,3\%. ${ }^{5}$

Status karies penduduk berada dalam kategori sedang, sedangkan pengujian kadar fluor menunjukkan hasil rendah. Hal ini merupakan sebuah kontradiksi dan membuat penulis berasumsi tentang berapa hal yang berkaitan dengan penelitian ini.

Ada beberapa faktor yang berpengaruh dalam status karies.Salah satu faktornya adalah pengetahuan.Penulis berasumsi penduduk di lokasi penelitian banyak mendapatkan informasi mengenai bagaimana menjaga kesehatan dan kebersihan gigi geligi dari media elektronik.Dewasa ini telah banyak informasi tentang bagaimana menjaga dan merawat gigi geligi yang disiarkan melalui siaran televisi maupun radio. Media lain yang bisa digunakan untuk mencari informasi tentang kesehatan gigi geligi ialah internet. Informasi mengenai internet bisa diakses siapa saja dan dimana saja termasuk dari telepon gengam, sehingga mereka boleh mendapatkan informasi kesehatan gigi geligi yang terbaru.

Pengetahuan cara menyikat gigi dengan baik dan benar juga bisa didapatkan dari orang tua mereka. Peran orang tua disini sangat penting dalam memberi pengetahuan tentang kesehatan gigi geligi.Penulis berasumsi para orang tua para responden sering mengingatkan untuk menjaga kesehatan gigi dan mulut mereka dan tidak lupa untuk menyikat gigi sebelum tidur. Para orang tua juga sering mengganti sikat gigi anak mereka tepat waktu, dan pasta gigi yang digunakan akan diganti secepatnya ketika pasta gigi telah habis. Hal ini yang membuat penduduk di desa Wiau Lapi Barat status kariesnya sedang, meskipun kadar fluornya sangat rendah.

Penulis melihat lagi bahwa tingkat perekonomian penduduk rendah, tidak seperti penduduk di kota. Hal ini membuat penulis berasumsi bahwa penduduk tidak terlampau sering mengonsumsi makananmakanan yang bersifat kariogenik seperti coklat.Seperti kita ketahui bahwa makanmakan kariogenik menjadi substrat yang baik dalam pembentukan karies.Karena tingkat perekonomian rendah juga, maka penduduk jarang mengonsumsi minuman bersifat kariogenik yang mengandung banyak gula terutama yang berkarbonasi karena harganya yang cukup mahal. Berbeda dengan masyarakat kota yang tingkat ekonominya lebih baik, mereka lebih mampun untuk membeli minuman ataupun makanan yang lebih mahal.

Tingkat ekonomi yang rendah juga yang menyebakan pada umumnya masyarakat di desa Wiau Lapi Barat lebih sering mengonsumsi makanan laut yang notabene lebih murah dan lebih banyak mengandung mineral yang lebih tinggi dibandingkan makanan lainya. Makanan laut mempunyai kadar fluor bisa mencapai 1,0 ppm, sedangkan pada daging biasa hanya berkisar 0,1-0,2 ppm. Apalagi pada masakan yang tulangnya ikut termakan dalam konsumen, seperti bentuk ikan kalengan ataupun bentuk pepes. Makanan dalam bentuk ini 
mempunyai kadar fluor lebih tinggi dari daging makanan laut biasa.

Salah satu hal yang memengaruhi status karies adalah faktor lingkungan, dan salah satunya adalah faktor lingkungan sosial.Penulis berasumsi bahwa lingkungan keluarga dan teman-teman dari responden menyadari pentingnya menjaga kesehatan gigi.Hal ini menyebabkan responden juga merawat kesehatan gigi geligi. Meskipun kadar fluor dalam air yang dikonsumsi rendah, tetapi karena lingkungan penduduk di lokasi penelitian mendukung dalam perawatan gigi, maka menyebabkan status karies penduduk rendah.

Secara kualitas penyediaan air bersih khususnya air minum harus sesuai dengan standar peraturan Menteri Kesehatan Republik Indonesia Nomor 492/ MENKES / PER / IV / 2010 tentang pengawasan kualitas air bersih. Untuk memenuhi standar, air bersih yang digunakan masyarakat harus memenuhi syarat fisik, kimia, bakteriologis, dan radio aktif.

Berdasarkan hasil pemeriksaan dan analisa kadar fluor yang dilakukan di laboratorium, 4 sampel air yang diambil dari 4 sumber air lingkungan di jaga satu sampai jagaempat menunjukkan kadar fluor sebesar 0,00 ppm. Hal ini tidak memenuhi syarat kesehatan sesuai dengan peraturan Menteri Kesehatan Republik Indonesia Nomor 492/ MENKES / PER / IV / 2010 tentang syaratsyarat dan pengawasan kualitas air yaitu kadar fluor sebesar $1,5 \mathrm{mg} / \mathrm{l}^{6}$

Kadar fluor yang ada di dalam air di sumber air desa Wiau Lapi Barat, berdasarkan alat spektrometer dengan panjang gelombang $525 \mathrm{~nm}$ yang digunakan oleh penulis menunjukkan hasil sebesar 0,00 ppm. Hal ini terjadi karena alat penelitian yang digunakan penulis hanya bisa mencapai dua angka desimal dibelakang koma.Ini yang menjadi keterbatasan penelitian yang ada didalam penelitian penulis. Penulis yakin, jika menggunakan alat lainnya atau alat yang mempunyai kompetensi lebih baik, maka analisis fluor akan lebih spesifik dan hasilnya akan lebih detail.
Air minum di sekitar daerah pesisir mendapatkan suplai air dari air tanah maupun resapan aliran air laut yang mengandung mineral fluor sehingga masyarakat yang tinggal di daerah tersebut mempunyaikadar fluor lebih tinggi daripada masyarakat di tempat lainnya. Di daerah pegunungan yang tinggi seperti desa Wiau Lapi Barat, kadar fluor dalam tanah rendah. Kadar fluor yang tinggi juga ditemui pada daerah dengan aktifitas vulkanik seperti gunung berapi. Di sekitar lokasi penelitian tidak terdapat aktifitas vulkanik sehingga hal ini menyebabkan sebagai salah satu faktor yang membuat kadar fluor di desa Wiau Lapi Barat kecil.

Kadar fluor dalam air juga meningkat apabila terdapat pabrik pengolahan barang tambang, karena dalam praktiknya pengolahan hasil tambang banyak menghasilkan fluor sebagai residu pengolahan hasil tambang. Residu dari hasil pengolahan tambang ini akan menaikkan kadar fluor dalam air di daerah tersebut. Di sekitar desa Wiau Lapi Barat tidak ditemukan pabrik pengolahan barang tambang sehingga kadar fluor di desa Wiau Lapi Barat juga tidak besar.

Kadar fluor yang tinggi juga ditemukan pada daerah yang memiliki tanah berstruktur gamping dan struktur batu kapur. Di sekitar daerah desa Wiau Lapi Barat, penulis tidak menemukan adanya strukur bebatuan gamping ataupun kapur, sehingga kadar fluor dalam air biasanya rendah.

Keadaan kedalaman sumber air juga mempengaruhi kadar fluor dalam air. Semakin dalam tanah, maka semakin tinggi juga kadar mineral yang terlarut dalam air. Penulis melihat kedalaman sumur di desa Wiau Lapi Barat rendah, dibawah sepuluh meter, sehingga kadar mineral yang terlarut di dalam sumber air di desa Wiau Lapi Barat kecil.

\section{SIMPULAN DAN SARAN}

Status karies penduduk usia 12-14 tahun di desa Wiau Lapi Barat berdasarkan pemeriksaan indeks karies berada dalam status karies sedang. Kadar fluor air yang 
dikonsumsi di desa Wiau Lapi Barat dengan menggunakan alat spektrofotometer menunjukkan hasil yang sangat rendah.

Data hasil penelitian ini akan diberikan kepada pemerintah supaya pemerintah mempunyai data-data akurat untuk mengadakan program-program penyuluhan kesehatan gigi dan mulutHasil dari penyuluhan kesehatan akan menyebabkan meningkatnya pemahaman penduduk tentang perawatan kesehatan gigi dan mulut sehingga derajat kesehatan gigi dan mulut bisa meningkat.

\section{DAFTAR PUSTAKA}

1. Kidd, Edwina. Fejerskof, Ole. Dental caries : The disease and it's clinical management. Black Munksgard Ltd. Iowa. 2008. p. 124-5.

2. Badan Penelitian dan Pengembangan Kesehatan. Riset Kesehatan Dasar 2007. Available from Http://www.litbangdepkes.go.id/Riskesdas2 007 [Cited : 2013 May 21]

3. Ongole, Praeven. Clinical manual for oral medicine and radiology. Jaypee brothers medical publishers (P) Ltd. New Delhi. 2007. p. 135- 6

4. Agtini, M.D. Siatawati, Tjahja Indirawati. Fluor dan kesehatan gigi. Media Litbang Kesehatan Volume XV nomor 2 tahun 2005. p. 25- 30.

5. Berwulo, Hendry. Gambaran status karies dan status kebersihan mulut desa Ranowangko kecamatan Kombi kabupaten Minahasa. Skripsi. Manado. 2011. hal 33.

6. Insyirah, Nur. Analisis Kadar fluor dalam air minum isi ulang pada depot pengisisan air di kecamatan Medan Selayang pada tahun 2011. USU. 2012. Medan. p.8 